Vol. 10(11), pp. 351-358, 16 June, 2015

DOI: $10.5897 /$ IJPS2015.4356

Article Number: D38B8DE53647

ISSN 1992 - 1950

Copyright (C2015

International Journal of Physical

Author(s) retain the copyright of this article

Sciences

http://www.academicjournals.org/IJPS

\title{
Outdoor performance analysis of a monocrystalline photovoltaic module: Irradiance and temperature effect on exergetic efficiency
}

\author{
Cheikh El Banany ELHADJ SIDI ${ }^{1 *}$, Mamadou Lamine NDIAYE ${ }^{1}$, Ababacar NDIAYE $^{1,2}$ and Papa \\ Alioune NDIAYE ${ }^{1}$
}

${ }^{1}$ Centre International de Formation et de Recherche en Energie Solaire (CIFRES)-Ecole Supérieure PolytechniqueUCAD, BP 5085 Dakar-Fann, Sénégal.

${ }^{2}$ Department de Physique, Université Assane Seck de Ziguinchor BP: 523 - Ziguinchor, Senegal.

Received 24 April, 2015 ; Accepted 26 May, 2015

\begin{abstract}
Studies realized on the performance of photovoltaic modules have shown that analysis of the effect of meteorological parameters is crucial in prediction and evaluation of performances; and production of solar systems. This paper highlights the performing analysis of a monocrystalline silicon photovoltaic module. The aim of this work is to study the effect of irradiance and temperature on module performance in a real environment. The variation of the exergy efficiency as a function of the module temperature on a day is presented. The electrical exergy rate and the thermal exergy losses rate of the module were examined. The findings of this study show that the exergetic efficiency depends on the variation of the irradiance and temperature during the day. Results give an exergetic efficiency of the module varying from 14.87 to $17.93 \%$ per day for monocrystalline $30 \mathrm{Wp} \mathrm{PV}$ module. The results also show a variation of exergetic efficiency for the same irradiance and decrease in efficiency with increasing module operating temperature. This decrease is $17.5 \%$ for an increase of $10 \mathrm{~K}$ (irradiance= $900 \mathrm{~W} / \mathrm{m}^{2}$ ). The thermal exergy losses rate increases with the difference between the module's operating temperature and the ambient temperature. It reaches its maximum $(3.36 \mathrm{~W})$ for a temperature difference equal to $28.9 \mathrm{~K}$.
\end{abstract}

Key words: Exergy, monocrystalline photovoltaic, performance analysis, efficiency, temperature, thermal exergy Losses, Outdoor.

\section{INTRODUCTION}

Fossil resources into reserves diminish substantially. Moreover, their use emits into the atmosphere the carbon dioxide gas which is recognized as one of the leaders of global warming. The global energy situation increasingly critical allowed a resurgence of interest in the scientific community for the use of sources of clean and / or renewable energy instead of traditional energy sources. Renewable energy sources contribute more to meeting energy needs. Among renewable technologies, solar systems are best suited to cover certain energy needs.

*Corresponding author. E-mail :benany17@gmail.com, Tel: +221776902924.

Author(s) agree that this article remain permanently open access under the terms of the Creative Commons Attribution

License 4.0 International License 
Indeed, the climate of Dakar is known for its long sunny days $\left(8.25 \mathrm{kWh} / \mathrm{m}^{2} / \mathrm{d}\right.$ to the most favorable month and $4.37 \mathrm{kWh} / \mathrm{m}^{2} / \mathrm{d}$ for the worst month) (Ould et al., 2007). The design and feasibility of photovoltaic systems mainly depend on the available potential and also the performance of the system under the conditions of the installation site. Production and performance of a photovoltaic module are highly bound to sunlight and cell operating temperature. The evaluation of the effect of the variation of meteorological parameters is extremely important in the prediction and estimation of performances taking into account the actual operating conditions of power systems based on photovoltaic modules. The installed system on a site is likely to behave differently if installed on another place. This difference results from the variation of meteorological parameters (Touati et al., 2013; Kamkird et al., 2012). Temperature plays an important role in the solar photovoltaic conversion process. It directly affects the electrical power of the photovoltaic module and consequently the efficiency of the photovoltaic system. Temperature affects the electrical parameters of the PV generator (module). As a result, the module's operating temperature is an important parameter in assessing and predicting the performance of photovoltaic systems (Radziemska and Kulgmann, 2002; Skoplaki et al., 2008). The prediction of output of the modules must take into account the electrical, physical and thermal properties of the cells, the solar radiation, the weather data and the transfer of heat with the environment (Skoplaki et al., 2008).

The effect of the operating temperature on the performances of a photovoltaic module (polycrystalline silicon) has been studied by Malik et al. (2009) under the conditions of Brunei for a period of 2 years. They found that the maximum power, the efficiency and the module fill factor are degraded at high operating temperatures, but a linear relationship cannot be correlated with different variables. This decrease is due to thermal agitation which also increases the loss of free carriers. For building-integrated photovoltaic (BIPV) modules, analyses of electrical and thermal performances have a great importance and should be taken into account in their implementation. Performances of this kind of photovoltaic modules have been studied by Park et al. (2010) in the standard test conditions (STC) and outdoor actual conditions of implementation. The properties of glass supporting photovoltaic cells and its effect on the temperature of the modules were examined. They concluded that the panels produce more electricity in winter than in summer, and the modules with clear glass are more efficient than those with bronzed glass. The results showed that in the STC, the voltage is reduced by $0.49 \%$ and the current increases with $0.01 \%$ for the increase of one degree Celsius. However, electricity production decreased by $0.48 \%$ in regard to the same increase of temperature.
Monitoring of the production and performances of energy systems based on photovoltaic panels in the real conditions of operation of the specific implementation site is of great importance to estimate the reliability and the production of these systems (Ndiaye et al., 2013a; Van Dyk et al., 2002, 2005; Al-Sabounchi et al., 2013). The purpose of monitoring is to assess the performances of photovoltaic modules and their behavior in the short and long-term. In this work we use the thermodynamic analysis (exergy analysis), which is a tool for assessing the performance of conventional and renewable energy systems. This method is adopted to quantify the thermodynamic losses in the process of converting solar energy into electrical energy. The exergetic analysis is used by many academics in evaluating the performances of energy systems such as power plant gas turbines, the drying processes and cooling etc. (Kotas, 1995). Recently this method of analysis was used in the analysis of based renewables energy systems by several researchers (Dincer and Rosen, 2007; Baskut et al., 2010, 2011; Joshi et al., 2009; Vats and Tiwari, 2012; Xydis, 2012; Sahin et al., 2006). Through the theory, a first search that analyzes the thermodynamic aspects of these systems is that of Koroneos et al. (2003). Specifically, Exergy analysis was applied to photovoltaic systems by several researchers. Regarding the conversion of solar energy systems, Akyuz et al. (2012) proposed an approach to determining the maximum value of solar radiations arriving on the surface of a photovoltaic system in order to evaluate the exergetic efficiency. Their approach involves the position of the sun during the day time and angle of incidence. The results show that the maximum exergetic efficiency corresponds to a low wind speed, a minimum ambient temperature and a high global solar radiation.Using the second law of thermodynamics, Sudhakar and Srivastava (2013) evaluated the energetic and exergetic efficiencies of a photovoltaic solar module ( $36 \mathrm{Wp})$. The module electrical parameters and those of operation are included in the calculation of energetic efficiency (6-9\%) and exegetic efficiency (8-10\%). Pandey et al. (2013) examined the performances of polycrystalline silicon modules with exergy analysis. Also, Sarhaddi et al. (2009) have developed an optimization method using exergy analysis to determine the design parameters and optimum performances of a photovoltaic panel. For a wind / PV hybrid system a study was conducted by Xydis (2013) to evaluate the exergetic efficiency. They introduced the exergy capacity factor (EXCF) which is the ratio of net energy provided by the system (kWh) on the total installed capacity (kW) multiplied by the number of hours of the year $(\mathrm{h})$. They identified temperature and strong sunlight losses as the parameters that most affect the performances of photovoltaic modules in the hybrid system.

An obstacle that limits the development of renewable electrical systems is their low efficiency and lack of 
performance data in terms of the actual environment in locations where they are installed. Production and performances of a photovoltaic module are highly dependent on sunlight and operating temperature of cell (Yang et al., 2007).

Our analysis is performed on a photovoltaic module (30 $\mathrm{Wp}$ ) whose performance is studied with respect to the variation of meteorological parameters (irradiance and temperature). The short-circuit current, open circuit voltage and module temperature were measured. The results of the analysis of the exergetic efficiency, the electrical exergy rate and the thermal exergy losses rate as function of the increase of the module temperature are presented.

\section{MATERIALS AND METHODS}

The methodological approach in this work consist of 3 steps:

(i) Acquisition of meteorological parameters and experimental data for the production of a photovolataic module.

(ii) Analyzing the effect of the irradiance and temperature on photovoltaic module efficiency through exergetic analysis.

(iii) Evaluating the thermal exergy losses rate of the module as function of temperature in sunny and cloudless day.

Exergy analysis is a tool for design and evaluation of energy systems. It is designed to evaluate the systems that begin in equilibrium but do not stay in mutual equilibrium with the environment during the process of energy conversion. Exergy is defined as the measure of the maximum useful work that can be provided by a system interacting with its environment has a pressure $P_{0}$ and temperature $T_{0}$ (Dincer and Rosen, 2007). Exergy can be associated with several forms of transfers such as the transfer of work, heat, material flow and others (Kotas, 1995). In the case of a system in equilibrium with its environment where conditions of mechanical equilibrium, thermal, electrical etc. are equal to those of the environment, exergy is zero. Exergy has the characteristic that it is destroyed when an irreversible process happens. When an exergetic analysis is performed on a process or system, the thermodynamic imperfections are quantified as quality losses of energy. This analysis method is adopted to identify the thermodynamic losses of energy systems. An important concept in exergy analysis is the exergetic efficiency for assessing the performance of an energy system taking into account the limitations imposed by the second law of thermodynamics.

The output power and the performances of photovoltaic modules are highly depending on sunlight, operating temperature and other weather parameters such as the accumulation of dust, a natural phenomenon characteristic of desert climates. Ndiaye et al. (2013b) have shown the importance of removing dust from the surface of the modules to ensure better performances and efficiency of photovoltaic modules. In our case, the effect of dust is not investigated. Indeed, the module was clean in the period of study. Generally, photovoltaic modules operate in operating conditions different from the operating standard conditions (STC), where the modules operating temperature is often greater than that in the STC. The increase of the ambient temperature and sunlight lead to a growth of the module's operating temperature $\left(T_{C}\right)$ which can be estimated by linear approximation by Kenny formula (Kenny et al., 2006):
$T_{C}=T_{a}+\left(\frac{T_{N O C T}-20}{G_{N O C T}}\right) G$

Where $G$ is the irradiance $\left(W / m^{2}\right), T_{a}$ is the ambient temperature, $T_{N O C T}$ is module temperature under nominal operating conditions (wind speed $=1 \mathrm{~m} / \mathrm{s}, \quad G_{N O C T}=$ $800 \mathrm{~W} / \mathrm{m}^{2}$ and $T_{a}=20^{\circ} \mathrm{C}$ ) and $G_{N O C T}$ is the irradiance under nominal operating conditions.

The generated power and the performances of photovoltaic modules depend on weather parameters such as ambient temperature $\left(T_{a}\right)$, irradiance $(G)$, wind speed $\left(v_{w}\right)$ etc. It also depends on the intrinsic parameters of photovoltaic modules Technology: the short circuit current $\left(I_{s c}\right)$, the maximum output current $\left(I_{\max }\right)$, the open circuit voltage $\left(V_{o c}\right)$, the maximum output voltage $\left(V_{\max }\right)$ and the module surface $(A)$. The output exergy rate of the photovoltaic module ( $E x_{P V}$ ) is the electrical exergy rate $\left(E x_{\text {ele }}\right)$ which is equal to the electric power generated by the module:

$$
E x_{P V}=E x_{\text {ele }}
$$

The electrical exergy rate is the maximum power generated by the photovoltaic module. It is given by Equation (3) (Ndiaye et al., 2014; Notton et al., 2005).

$$
E x_{\text {ele }}=F F \times V_{o c} \times I_{s c}
$$

The solar radiation exergy rate $\left(E x_{\text {radiation }}\right)$ which reaches the module surface $(A)$ is expressed according to the theorem of Patela (Patela, 2003) and given by the following expression (temperature is expressed in Kelvin subsequently):

$$
E x_{\text {radiation }}=A G\left(1-\frac{4}{3}\left(\frac{T_{a}}{T_{s}}\right)+\frac{1}{3}\left(\frac{T_{a}}{T_{s}}\right)^{4}\right)
$$

Where $T_{s}$ is the sun's temperature which is equal to $5762 \mathrm{~K}$.

The thermal exergy losses rate through the solar conversion process is in the form of heat loss from the surface of the module to the outside. Photovoltaic modules heat up because of their exposure to sunlight and emit quantity of heat into the environment. This heat source is not in equilibrium with the environment; and consequently possesses an exergy which represents the thermal losses of the photovoltaic module (Akyuz et al., 2012).

$$
E x_{\text {losses }}=Q\left(1-\frac{T_{a}}{T_{C}}\right)
$$

The convective heat transfer rate is given by the following equation:

$$
Q=h_{e c} A\left(T_{C}-T_{a}\right)
$$


Table 1. specifications (STC) of photovoltaic module used in experimentation.

\begin{tabular}{lc}
\hline Specifications & Values \\
\hline Nominal Peak power (Watts) & 30 \\
Short-circuit current (Ampers) & 2.24 \\
Open-circuit voltage (Volts) & 22.50 \\
Fill Factor $(-)$ & 0.72 \\
PV cell surface $\left(\mathrm{cm}^{2}\right)$ & 49 \\
Cells number $(-)$ & 36 \\
\hline
\end{tabular}

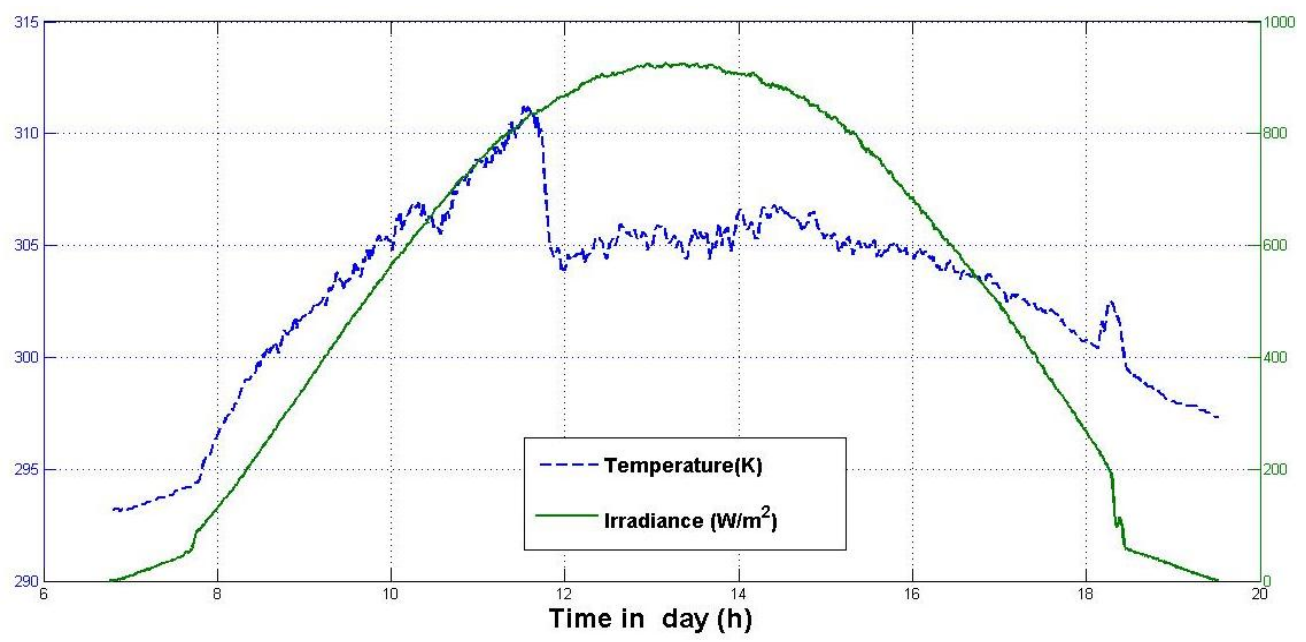

Figure 1. Daily variation of irradiance and ambient temperature (one sunny day).

The parameter $\left(h_{e c}\right)$ is the convective heat transfer coefficient between environment and module and whose expression is given by:

$$
h_{e c}=5.7+3.8 v_{w}
$$

In this work the wind speed was not measured. It is taken under nominal operating conditions $\left(v_{w}=1 \mathrm{~m} / \mathrm{s}\right.$ ) to quantify the heat loss of the module.

\section{RESULTS AND DISCUSSION}

In order to evaluate the performances of the photovoltaic module, we use the exergetic efficiency. The exergetic efficiency of solar energy conversion process into electrical energy (Equation 8 ) is defined as the ratio of exergy useful (electrical exergy rate) Equation (3) on exergy of the solar radiation rate Equation (4):

$$
\varepsilon_{P V}=\frac{\mathrm{FF} \times V_{o c} \times I_{s c}}{A G\left(1-\frac{4}{3}\left(\frac{T_{a}}{T_{s}}\right)+\frac{1}{3}\left(\frac{T_{a}}{T_{s}}\right)^{4}\right)}
$$

The data of irradiance and ambient temperature are measured at the Higher Polytechnic School (ESP) of the Dakar University in Senegal $\left(17.28^{\circ}\right.$ West longitude and $14.43^{\circ}$ North latitude). In the same environment, a single crystal photovoltaic module $(30 \mathrm{Wp})$ was installed and the short-circuit current, the open circuit voltage of the module and its temperature was collected. The characteristics of a photovoltaic module used in the experiment are given in Table 1.

Irradiance and module temperature are plotted for a day in Figure 1. Temperature increases and decreases simultaneously with irradiation. Consequently in a real environment it is difficult to discern the effect of temperature on performances of the photovoltaic module. The evolution of exergy of the solar radiation rate and electrical exergy rate are plotted for one sunny day in the Figure 2. The electrical exergy rate increases from zero to $7 \mathrm{~h} 15 \mathrm{~min}$ until $26.7 \mathrm{~W}$ at $13 \mathrm{~h} 22 \mathrm{~min}$ and then decreases again to zero at $19 \mathrm{~h} 32 \mathrm{~min}$.

The variation for this day of the exergetic efficiency is given in Figure 3. It depends on the time of day and depends on the sunshine and temperature simultaneously. In fact it varies from 14.87 to $17.93 \%$ of irradiance and temperature combination of the day.

In order to analyze the effect of temperature on 


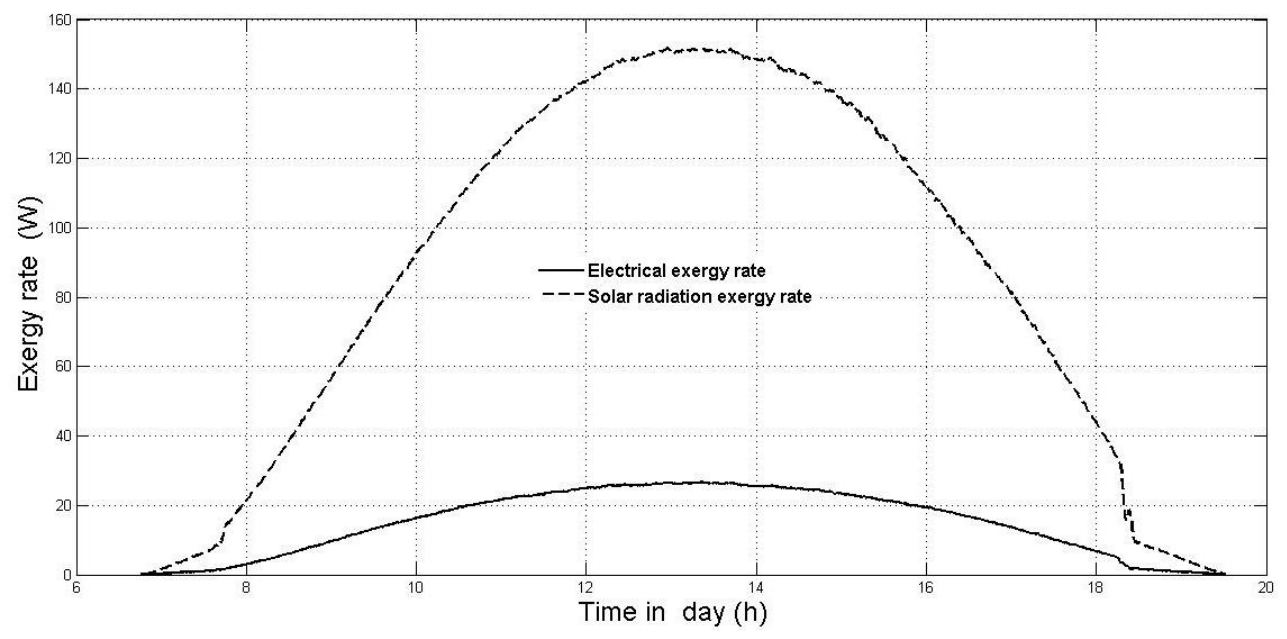

Figure 2. Daily variation of electrical exergy rate and solar radiation exergy rate (one sunny day).

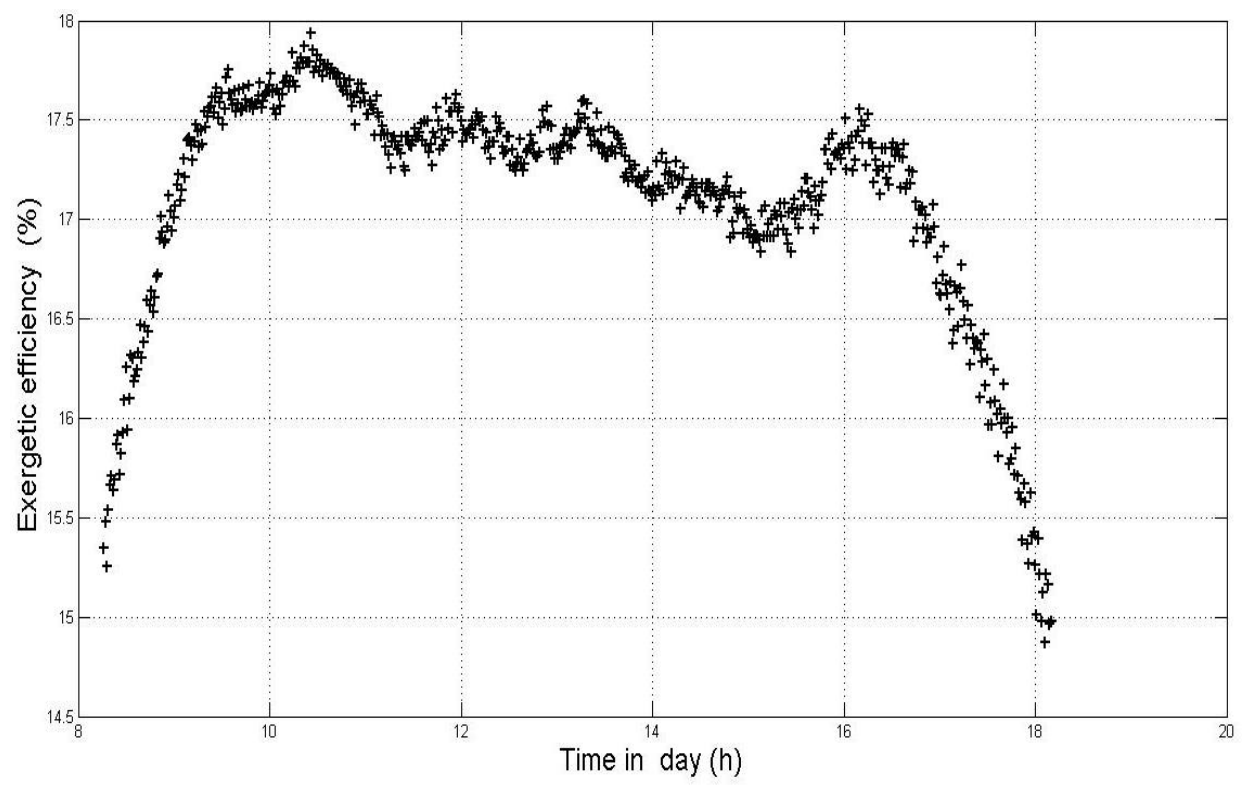

Figure 3. Daily variation of exergetic efficiency (one sunny day).

exergetic efficiency, data from 6 to 18 June 2012 are used and the data corresponding to the irradiances 500 and $900 \mathrm{~W} / \mathrm{m}^{2}$ are selected. In Figure 4, the variation of exergetic efficiency as a function of temperature for the irradiances of 500 and $900 \mathrm{~W} / \mathrm{m}^{2}$ respectively is shown. From Figures 3 and 4, we can see that the exergetic efficiency of the module is not constant and varies in a real environment according to the instantaneous irradiance and temperature. For an irradiance of 500 $W / m^{2}$, the efficiency decreases by $4.2 \%$ to an increase of $9.3 K \quad(316.2$ to $325.5 K)$ module temperature; while for $900 \mathrm{~W} / \mathrm{m}^{2}$, the efficiency decreases by $17.5 \%$ to an increase of $10 \mathrm{~K}$ (329.9 to $339.9 \mathrm{~K})$. This results show that for a constant irradiance, the exergetic efficiency decreases with increasing temperature. The dependence of the efficiency on rising in temperature is greater when the irradiance is larger. As part of a large photovoltaic installation of several $\mathrm{kWp}$ to $\mathrm{MWp}$, this reduction in the yield due to the operating temperature can greatly affect the total output of the system.

The thermal exergy losses rate during the conversion process is quantified using the Equation (5). Its variation during the day is given in Figure 5 . It can be seen that the maximum of the heat losses magnitude corresponds to the hours of the day when the irradiance and module 


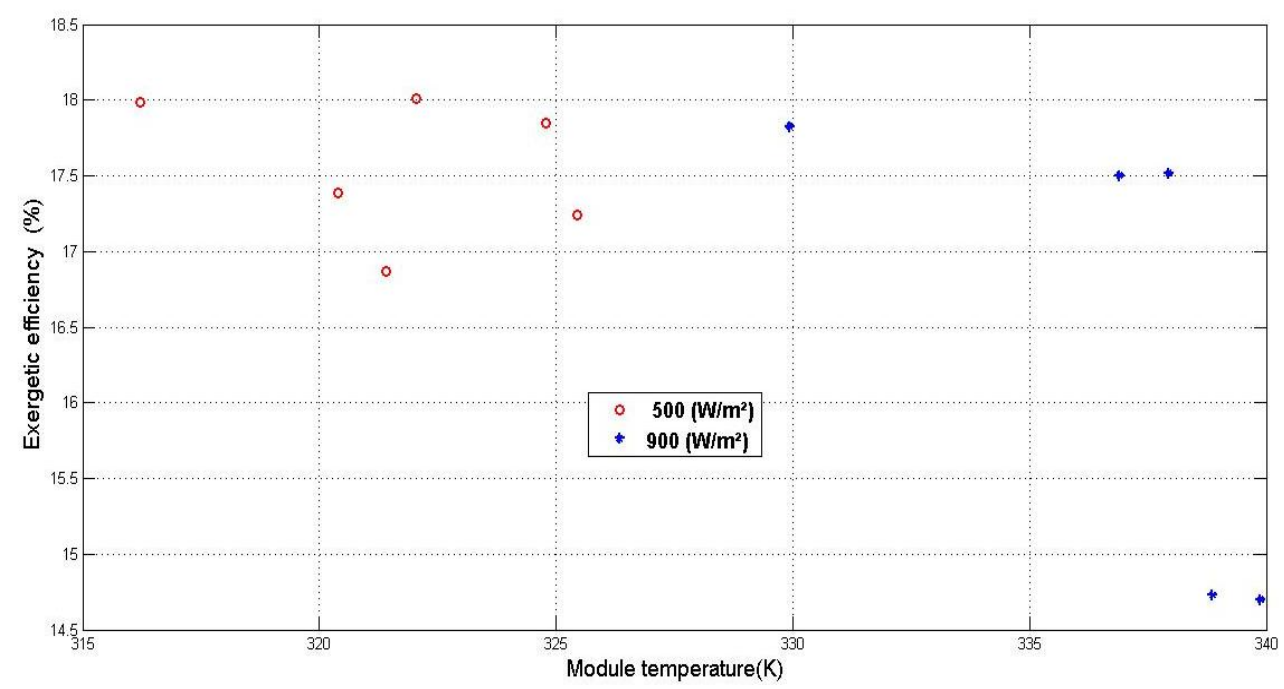

Figure 4. Exergetic efficiency versus module temperature for irradiance values equal to 500 and $900\left(W / m^{2}\right)$.

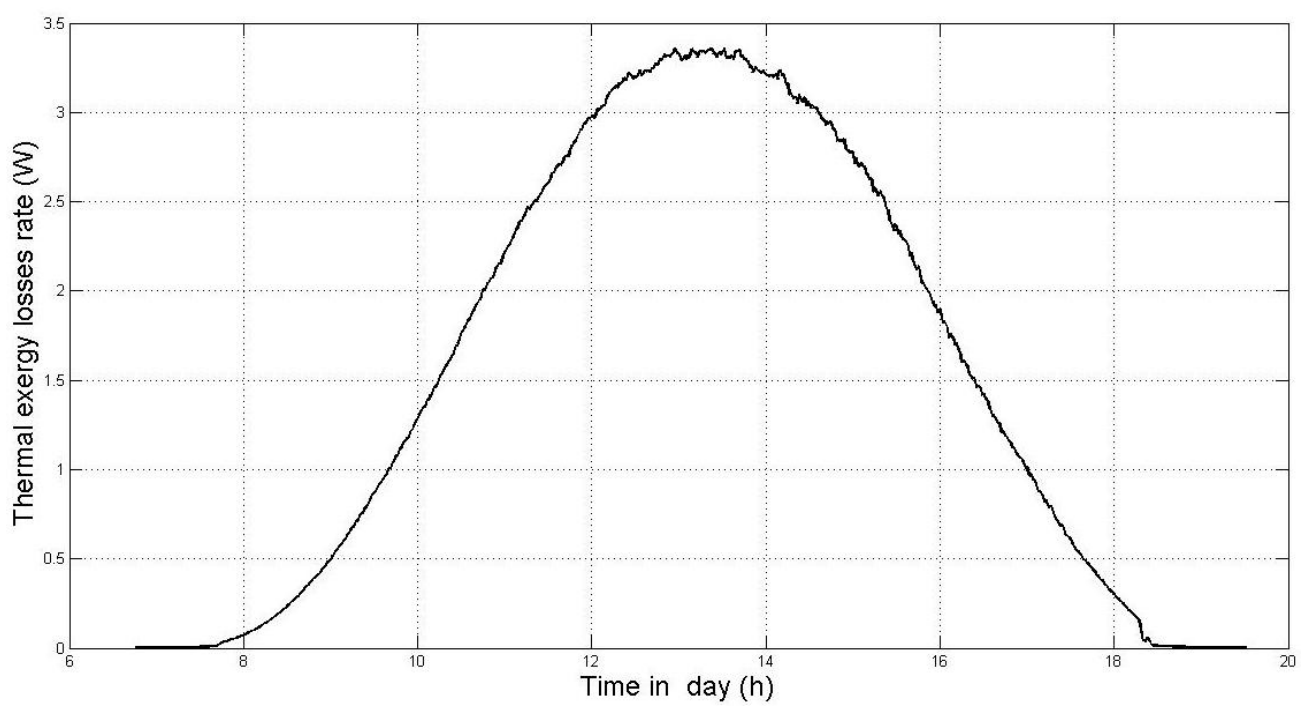

Figure 5. Daily variation of the thermal exergy losses rate (one sunny day).

temperature are maximal. The variation of the thermal exergy losses rate depending on the difference between the module temperature and the ambient temperature $\left(T_{C}-T_{a}\right)$ is given in Figure 6. From this figure it is clear that the thermal exergy losses rate increases with the difference between $T_{C}$ and $T_{a}$. When this difference reaches its maximum in the daytime $(28.9 \mathrm{~K})$, the thermal exergy losses rate its maximum which is equal to $3.36 \mathrm{~W}$.

In order to better harness the waste heat from the module, other researchers like Dubey et al. (2009) proposed the use of hybrid photovoltaic and thermal module (PVT). This device converts the absorbed solar radiation into electricity and heat can be used simultaneously to heat water or air. PVIT system consists of a photovoltaic module integrated with a solar heat collector providing heat. The PVIT system benefits from the heat to generate more energy per unit area. Integrating PVT systems can be a viable way that produces electricity in combination with air or hot water for installations in buildings. Abdolzadeh and Ameri (2009) proposed to consider installing water spray systems on photovoltaic panels in pumping systems to 


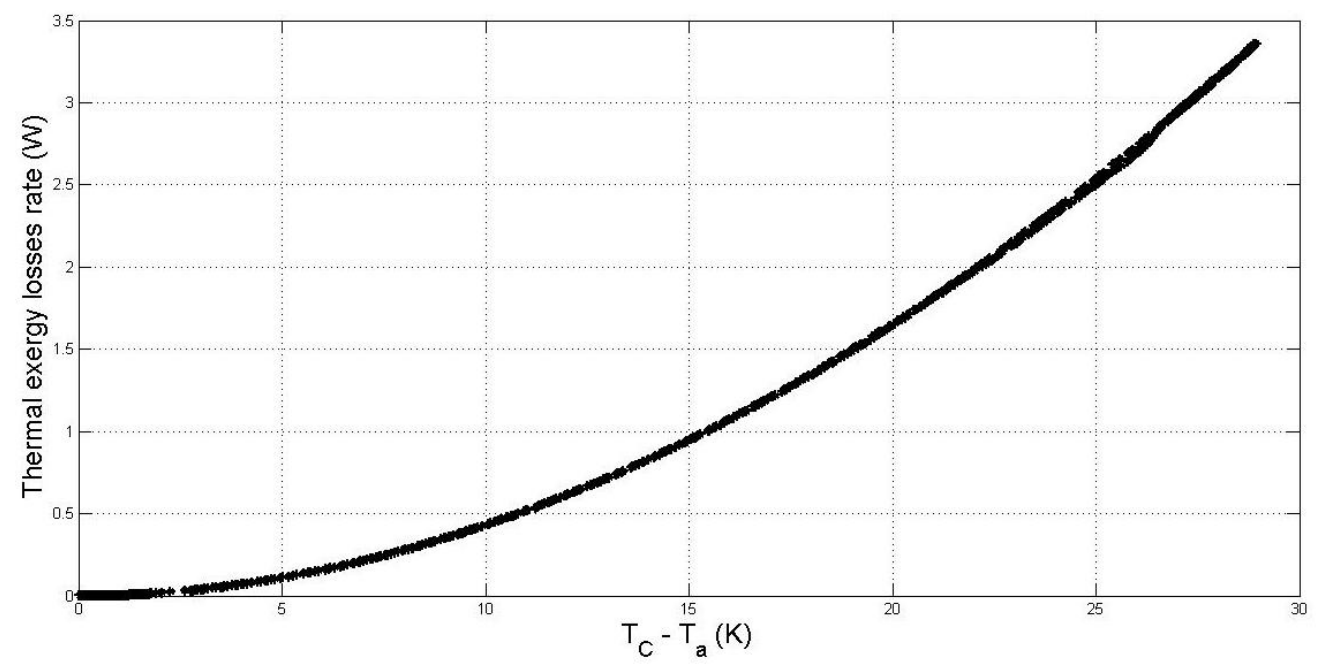

Figure 6. Variation of the thermal exergy losses rate versus (one sunny day).

improve their performances by reducing the temperature of the cells through the glass and clean the dust. Their results showed that irrigation may reduce the operating temperature of $23^{\circ} \mathrm{C}$ and increase the yield of $3.26 \%$.

\section{Conclusion}

Exergy analysis was performed to a monocrystalline photovoltaic module $(30 \mathrm{Wp})$ in a real environment. The effect of irradiance and temperature on performances was examined and produced electrical exergy rate and thermal exergy losses rate of the photovoltaic module were quantified for one day. The results of this study confirmed the dependency of the exergetic efficiency of the module to the variation of the irradiance and temperature. These findings can be summarized as followed:

(i) The exergetic efficiency of the module varies from 14.87 to $17.93 \%$ as claimed in irradiance and temperature combination of the day.

(ii) For the same irradiance, the exergetic efficiency decreases with the increase in module temperature. This decrease is $17.5 \%$ for an increase of $10 K$ (329.9 to $339.9 \mathrm{~K}$ ) for constant irradiance about $900 \mathrm{~W} / \mathrm{m}^{2}$.

(iii) The thermal exergy losses rate increases with the difference between the module temperature and the ambient temperature. It reaches its maximum of $3.36 \mathrm{~W}$ for a temperature difference equal to $28.9 \mathrm{~K}$.

However, the exergetic efficiency is a function of the combination irradiance- temperature in a day. Furthermore, these parameters are randomized and depended on a season and a time of day. Therefore, it is difficult to discern the effect of each parameter separately on PV module performance in a real environment.

\section{Conflict of Interest}

The authors have not declared any conflict of interest.

\section{REFERENCES}

Abdolzadeh M, Ameri M (2009). Improving the effectiveness of a photovoltaic water pumping system by spraying water over the front of photovoltaic cells. Renewable Energy 34(1):91-96. http://dx.doi.org/10.1016/j.renene.2008.03.024

Akyuz E, Coskun C, Oktay Z, Dincer I (2012). A novel approach for estimation of photovoltaic exergy efficiency. Energy. 44(1):10591066. http://dx.doi.org/10.1016/j.energy.2012.04.036

Al-Sabounchi AM, Yalyali SA, Al-ThaniHamda A (2013). Design and performance evaluation of a photovoltaic grid-connected system in hot weather conditions. Renewable Energy. 53:71-78. http://dx.doi.org/10.1016/j.renene.2012.10.039

Baskut O, Onder O, Leyla O (2010). Effects of meteorological variables on exergetic efficiency of wind turbine power plants. Renewable Sustainable Energy Rev. 14(9):3237-3241. http://dx.doi.org/10.1016/j.rser.2010.06.002

Baskut O, Onder O, Leyla O (2011). Second law analysis of wind turbine power plants: Cesme, Izmir example. Energy 36(5):25352542. http://dx.doi.org/10.1016/j.energy.2011.01.047

Dincer I, Rosen M (2007). Exergy: Energy, Environment and Sustainable Development. Elsevier Science, ISBN: 978-0-08-0445298:472.

Dubey Swapnil, Sandhu GS, Tiwari GN (2009). Analytical expression for electrical efficiency of $\mathrm{PV} / \mathrm{T}$ hybrid air collector. Appl. Energy 86(5):697-705. http://dx.doi.org/10.1016/j.apenergy.2008.09.003

Joshi AS, Dincer I, Reddy BV (2009). Thermodynamic assessment of photovoltaic systems. Solar Energy http://dx.doi.org/10.1016/j.solener.2009.01.011

Kamkird P, Ketjoy N, Rakwichian W, Sukchai S (2012). Investigation on temperature coefficients of three types photovoltaic module technologies under thailand operating condition. Procedia Eng. 32:376-383. http://dx.doi.org/10.1016/j.proeng.2012.01.1282

Kenny RP, Dunlop ED, Ossenbrink HA, Müllejans H (2006). A practical 
method for the energy rating of $\mathrm{C}-\mathrm{Si}$ photovoltaic modules based on standard tests. Progress in Photovoltaics: Res. Appl. 14(2):155-166. DOI: $10.1002 /$ pip.658

Kotas TJ (1995).The exergy method of thermal plant analysis. Kerieger publishing company.

Koroneos C, Spachos T, Moussiopoulos N (2003). Exergy analysis of renewable energy sources. Renewable Energy. 28(2):295-310. http://dx.doi.org/10.1016/S0960-1481(01)00125-2

Malik AQ, Ming Lim C, Sheng Tan K, Blundell M (2009). Influence of temperature on the performance of photovoltaic polycrystalline silicon module in the Bruneian climate. ASEAN. J. Sci. Technol. Dev. 26(2):63-74.

Ndiaye A, Kébé CMF, Ndiaye PA, Charki Abdérafi KA, Sambou V (2013a). A Novel Method for Investigating Photovoltaic Module Degradation. Energy Procedia 36:1222-1231.

Ndiaye A, Kébé CMF, Ndiaye PA, Charki A, Kobi A, Sambou V (2013b). Impact of dust on the photovoltaic (PV) modules characteristics after an exposition year in Sahelian environment: The case of Senegal. Int. J. Phys. Sci. 8(21):1166-1173.

Ndiaye A, Kébé CMF, Ndiaye PA, Charki A, Sambou V, Kobi A, (2014). Degradation evaluation of crystalline-silicon photovoltaic modules after a few operation years in a tropical environment. Solar Energy 103:70-77. http://dx.doi.org/10.1016/j.solener.2014.02.006

Notton G, Cristofari C, Mattei M, Poggi P (2005). Modelling of a doubleglass photovoltaic module using finite differences. Appl. Thermal Eng. 25(17-18):2854-2877. http://dx.doi.org/10.1016/j.applthermaleng.2005.02.008

Ould Bilal B, Sambou V, Kébé CMF, Ndongo M, Ndiaye PA (2007). Etude et modélisation du potentiel solaire du site de Nouakchott et de Dakar. J. Sci. 7(4):57-66.

Pandey AK, Tyagi VV, Tyagi SK (2013). Exergetic analysis and parametric study of multi-crystalline solar photovoltaic system at a typical climatic zone. Clean Technol. Environ. Policy. 15(2):333-343.

Park KE, Kang GH, Kim HI, Yu GJ, Kim JT (2010). Analysis of thermal and electrical performance of semi-transparent photovoltaic (PV) module. Energy 35(6):2681-2687. http://dx.doi.org/10.1016/j.energy.2009.07.019

Patela R (2003). Exergy of undiluted thermal radiation. Solar Energy 74(6):469-488. http://dx.doi.org/10.1016/S0038-092X(03)00226-3

Radziemska E, kulgmann E (2002). Thermally affected parameters of the current-voltage characteristics of silicon photocell. Energy conver. manage. 43:1889-900. http://dx.doi.org/10.1016/S01968904(01)00132-7

Sahin AD, Dincer I, Rosen MA (2006). Thermodynamic analysis of wind energy. Int. J. Energy Res. 30(8):553-566. DOI: 10.1002/er.1163

Sarhaddi F, Farahat S, Ajam H, Behzadmehr A (2009). Exergetic Optimization of a Solar Photovoltaic Array. J. Thermodyn. 11 pages. http://dx.doi.org/10.1155/2009/313561
Skoplaki E, Boudouvis AG, Palyvos JA (2008). A simple correlation for the operating temperature of photovoltaic modules of arbitrary mounting. Solar Energy Mater. Solar Cells. 92(11):1393-1402. http://dx.doi.org/10.1016/j.solmat.2008.05.016

Sudhakar K, Srivastava T (2013). Energy and exergy analysis of 36W solar photovoltaic module. Int. J. Ambient Energy. DOI: 10.1080 /01430750.2013.770799

Touati FA, Al-Hitmi MA, Bouchech HJ (2013). Study of the Effects of Dust, Relative Humidity, and Temperature on Solar PV Performance in Doha: Comparison Between Monocrystalline and Amorphous PVS. Int. J. Green Energy. 10(7):680689.DOI:10.1080/15435075.2012.692134

Van Dyk EE, Meyer EL, Vorster FJ, Leitch AWR (2002). Long-term monitoring of photovoltaic devices. Renewable Energy. 25(2):183197. http://dx.doi.org/10.1016/S0960-1481(01)00064-7

Van Dyk EE, Gxasheka AR, Meyer EL (2005). Monitoring currentvoltage characteristics and energy output of silicon photovoltaic modules. Renewable Energy. 30(3):399-411. http://dx.doi.org/10.1016/j.renene.2004.04.016

Vats K, Tiwari GN (2012). Energy and exergy analysis of a building integrated semitransparent photovoltaic thermal (BISPVT) system. Appl. Energy 96:409-416. http://dx.doi.org/10.1016/j.apenergy.2012.02.079

Xydis G (2012). The wind chill temperature effect on a large-scale PV plant-an exergy approach. Progress Photovoltaics Progress Res. 21(8):1611-1624. DOI: 10.1002/pip.2247

Xydis G (2013). On the exergetic capacity factor of a wind-solar power generation system. J. Cleaner Prod. 47:437-445. http://dx.doi.org/10.1016/j.jclepro.2012.07.014

Yang HX, Lu L, Zhou W (2007). A novel optimization sizing model for hybrid solar-wind power generation system. Solar Energy. 81(1):7684. http://dx.doi.org/10.1016/j.solener.2006.06.010 